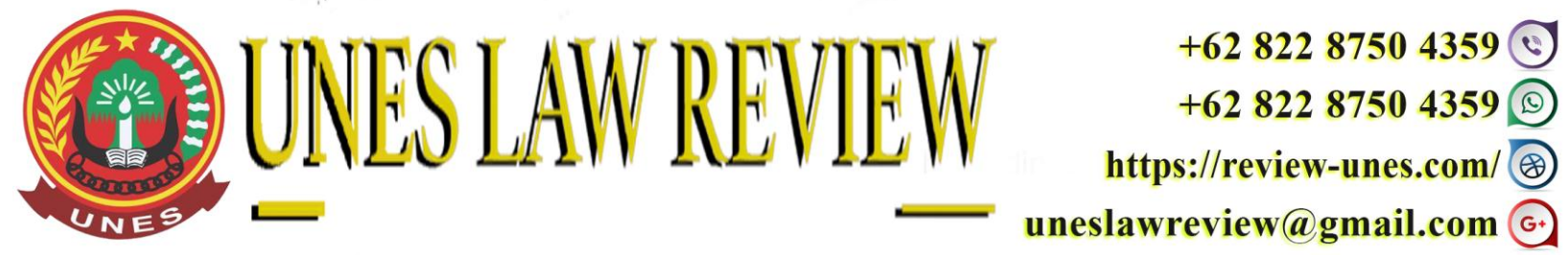

DOI: https://doi.org/10.31933/unesrev.v3i1

Diterima: 29/08/2020, Diperbaiki: 01/09/2020, Diterbitkan: 02/09/2020

\title{
PEMBATALAN SERTIPIKAT HAK MILIK OLEH KANTOR PERTANAHAN BERDASARKAN PUTUSAN PENGADILAN YANG TELAH BERKEKUATAN HUKUM TETAP DALAM PERKARA NOMOR:17/PDT.G/2009.PN.LB.BS
}

\author{
Roni $^{1}$, Zainul Daulay ${ }^{2}$, Beatrix Benni ${ }^{3}$ \\ 1) Program Magister Kenotariatan, Fakultas Hukum, Universitas Andalas, Padang, Indonesia. \\ Email: ronidjambak@gmail.com \\ 2) Program Magister Kenotariatan, Fakultas Hukum, Universitas Andalas, Padang, Indonesia. \\ Email: zdaulay@gmail.com \\ 3) Program Magister Kenotariatan, Fakultas Hukum, Universitas Andalas, Padang, Indonesia. \\ Email:pbeatrix_benni@yahoo.com
}

Corresponding Author: Beni

\section{ABSTRACT}

One of the objectives of land registration is to provide legal certainty for land rights holders. Therefore, in order to make this happen, regulations regarding land registration are made, one of which is Article 32 paragraph (2) PP Number 24 of 1997. However, in reality there are still problems in terms of ownership of a parcel of land associated with this article, namely against a plot of land which has been controlled by a legal subject for years and has been equipped with a certificate. There are still outsiders demanding rights to the land with respect to the land. Until now, Article 32 paragraph (2) Government Regulation Number 24 Year 1997, which should have been a solution to the above problems, still creates differences. Given the existence of this article is not in accordance with the negative publication system adopted by land registration in Indonesia, where a certificate is not an absolute evidence, but a certificate is strong evidence.

Kata Kunci: Pembatalan, Hak Atas Tanah, Putusan Pengadilan Berkekuatan Hukum Tetap

\section{PENDAHULUAN}

Pasal 1 butir (1) Peraturan Pemerintah Nomor 24 Tahun 1997 tentang pendaftaran tanah menyebutkan bahwa pendaftaran tanah adalah rangkaian kegiatan yang dilakukan oleh pemerintah secara terus menerus, berkesinambungan dan teratur, meliputi : pengumpulan, pengelolahan, pembukuan dan penyajian serta pemeliharaan data fisik dan data yuridis, dalam bentuk peta daftar, mengenai bidang-bidang tanah dan satuan-satuan rumah susun, termasuk pemberian surat tanda bukti haknya bagi bidang-bidang tanah yang sudah ada haknya dan hak 
atas satuan rumah susun serta hak-hak tertentu yang membebaninya. Dengan demikian pendaftaran ini tentunya dilakukan dengan sangat teliti dan tidak asal-asalan dan bukan hanya untuk sekedar timbul bukti pendaftaran (sertifikat), namun atas bukti tersebut dapat dipakai sebagai bukti yang benar (AP, 1994:3).

Peraturan Pemerintah Nomor 24 Tahun 1997 tentang pendaftaran tanah tetap mempertahankan tujuan dan sistem yang digunakan dalam Pasal 19 Undang-Undang No 5 Tahun 1960 tentang Peraturan Dasar Pokok-Pokok Agraria dan Peraturan Pemerintah Nomor 10 Tahun 1961 Tentang Pendaftaran Tanah. Peraturan Pemerintah Nomor 24 Tahun 1997, merupakan penyempurnaan dari peraturan sebelumnya sehingga banyak terdapat tambahan, hal ini terlihat dari jumlah Pasal yang lebih banyak dan isi Peraturan Pemerintah tersebut yang lebih memberikan jaminan kepastian hukum dalam hal kepemilikan tanah. Salah satunya terdapat dalam Pasal 32 Peraturan Pemerintah Nomor 24 Tahun 1997 tentang pendaftaran tanah yang mengatur bahwa sertipikat merupakan surat tanda bukti hak yang berlaku sebagai alat pembuktian yang kuat mengenai data fisik dan data yuridis yang termuat di dalamnya, sepanjang data fisik dan data yuridis tersebut sesuai dengan data yang ada dalam surat ukur dan buku tanah hak yang bersangkutan.

Jaminan kepastian hukum dipertegas lagi oleh ayat (2) Pasal tersebut yakni dalam hal suatu bidang tanah sudah diterbitkan sertipikat secara sah atas nama orang atau badan hukum yang memperoleh tanah tersebut dengan itikad baik dan secara nyata menguasainya, maka pihak lain yang merasa mempunyai hak atas tanah itu tidak dapat lagi menuntut pelaksanaan hak tersebut apabila dalam jangka waktu (5) lima tahun sejak diterbitkannya sertipikat itu tidak mengajukan keberatan secara tertulis kepada pemegang sertipikat dan kepala Kantor Pertanahan yang bersangkutan ataupun tidak mengajukan gugatan ke Pengadilan mengenai penguasaan tanah atau penerbitan sertipikat tersebut.

Ayat (1) Pasal ini mengandung makna bahwa sertipikat merupakan alat pembuktian yang kuat dan selama tidak dapat dibuktikan sebaliknya maka data fisik dan data yuridis yang tercantum dalam sertipikat harus diterima sebagai data yang benar, sedangkan ayat (2) lebih menegaskan lagi jaminan kepastian dan perlindungan hukum bagi pemegang sertipikat tanah, dimana mengandung beberapa syarat, diantaranya Sertipikat tanah diperoleh dengan itikad baik, Pemegang hak atas tanah harus menguasai secara fisik tanahnya selama jangka waktu tertentu serta keberadaan sertipikat tanah yang tidak dapat diganggu gugat lagi apabila sejak lima tahun diterimanya sertipikat hak atas tanah tidak ada keberatan dari pihak lainnya.

Ketentuan dalam Pasal 32 ayat (2) tersebut sebenarnya bukan merupakan suatu ketentuan baru, karena konsep dari Pasal ini merupakan konsep yang dipakai dalam menyelesaikan sengketa tanah pada hukum adat sebelum berlakunya Peraturan Pemerintah Nomor 24 Tahun 1997. Konsep yang digunakan dalam Pasal ini adalah "rechtsverwerking" yang sudah diterapakan sebelum Peraturan Pemerintah 24 Tahun 1997 berlaku bahkan jauh sebelum Undang-Undang No 5 Tahun 1960 tentang Peraturan Dasar Pokok-Pokok Agraria. Untuk itu ketika terjadi sengketa hak milik atas tanah seharusnya mampu diselesaikan secara efektif dengan Pasal tersebut. Dalam pendaftaran tanah, terdapat 5 (lima) asas pendaftaran tanah yang 
harus benar-benar dilaksanakan, salah satunya asas aman yang mengandung makna hati-hati, cermat, dan teliti, agar tidak terjadi suatu kekeliruan data yang dikumpulkan, sehingga kepastian hukum dapat tercapai.

Meskipun kepemilikan tanah telah diatur sedemikian rupa, namun masih saja terdapat permasalahan dalam hal kepemilikan sebidang tanah, misalnya saja terhadap sebidang tanah yang sudah dikuasai oleh subjek hukum selama bertahun-tahun dan telah dilengkapi dengan sertipikat. Terhadap tanah itu masih ada pihak luar yang menuntut hak atas tanah tersebut. Permasalahan ini sering terjadi di berbagai daerah di Indonesia. Tujuan dari penelitian ini adalah untuk mengetahui dan menganalisis proses pembatalan sertipikat hak atas tanah berdasarkan putusan pengadilan yang berkekuatan hukum tetap dan kaitannya dengan kompetensi peradilan yang berwenang mengadili sengketa pertanahan. Kemudian penelitian ini juga bertujuan untuk mengetahui akibat hukum pembatalan sertipikat hak atas tanah dan perlindungan hukum yang diberikan kepada pemegang sertipikat hak atas tanah terkait penerapan Pasal 32 ayat (2) Peraturan Pemerintah Nomor 24 Tahun 1997 dalam penyelesaian permasalahan di bidang pendaftaran tanah sehingga dapat diketahui jaminan kepastian kepemilikan sertipikat terhadap hak atas tanah

\section{METODE PENELITIAN}

Metode yang digunakan dalam penelitian ini adalah metode yuridis Empiris. Data Primer yang berhubungan dengan penelitian ini adalah diperoleh secara langsung dari penelitian lapangan dengan cara melakukan wawancara dengan responden yang berkompeten mengenai pembatalan sertipikat hak atas tanah dan didukung pula dengan data Sekunder yang dikumpulkan melalui studi dokumen-dokumen hukum.

\section{HASIL DAN PEMBAHASAN}

\section{Bagaimana Perbedaan Proses Pembatalan Sertipikat Hak Milik Berdasarkan Putusan Peradilan Umum Dan Peradilan Tata Usaha Negara.}

\section{Proses Pembatalan Sertipikat Hak Milik Berdasarkan Putusan Peradilan Umum.}

Pelaksanaan putusan pengadilan merupakan tindak lanjut atas putusan lembaga peradilan yang telah mempunyai kekuatan hukum tetap. Amar putusan menurut Pasal 124 ayat (2) PMNA/KBPN Nomor 9 Tahun 1999 Tentang Tata Cara Pemberian dan Pembatalan Hak Atas Tanah Negara dan Hak Pengelolaan yaitu ;

"Amar putusan pengadilan yang telah mempunyai kekuatan hukum tetap meliputi dinyatakan batal atau tidak mempunyai kekuatan hukum atau yang pada intinya sama dengan itu."

Sedangkan amar putusan dalam Pasal 49 ayat (2) PMNA/KBPN Nomor 11 Tahun 2016 tentang penyelesaian Kasus Pertanahan antara lain:
a. Perintah untuk membatalkan hak atas tanah;
b. Menyatakan batal/tidak sah/tidak mempunyai kekuatan hukum hak atas tanah;
c. Menyatakan tanda bukti hak tidak sah/tidak berkekuatan hukum;
d. Perintah dilakukannya pencatatan atau pencoretan dalam Buku Tanah; 
e. Perintah penerbitan hak atas tanah;

f. Amar yang bermakna menimbulkan akibat hukum terbitnya peralihan hak atau batalnya peralihan hak, atau yang pada intinya sama dengan itu.

Proses pembatalan karena melaksanakan putusan peradilan yang telah memperoleh kekuatan hukum tetap dilaksanakan atas permohonan pihak yang berkepentingan melalui Kantor Pertanahan setempat. Pihak yang berkepentingan tersebut merupakan para pihak penggugat maupun tergugat atau pihak lain yang terlibat dalam perkara.

Syarat yang pemohon lengkapi dalam mengajukan permohonan Pembatalan sertipikat hak milik antara lain:

a. Fotokopi identitas pemohon atau fotokopi identitas penerima kuasa dan surat kuasa apabila dikuasakan;

b. Salinan resmi putusan pengadilan yang telah mempunyai kekuatan hukum tetap yang dilegalisir pejabat berwenang;

c. Surat keterangan dari Pejabat berwenang di lingkungan pengadilan yang menerangkan bahwa putsan dimaksdu telah mempunyai kekuatan hukum yang tetap;

d. Berita acara pelaksanakan eksekusi, dalam hal putusan perkara yang memerlukan pelaksanaan eksekusi; Berita acara pelaksanaan eksekusi penguasaan/pengosongan/ penyerahan tanah tidak diperlukan dalam permohonan pembatalan sertipikat hak milik, dalam hal:

1) Untuk melaksanakan Putusan Pengadilan Tata Usaha Negara;

2) Tanahnya telah dikuasai pihak pemohon yang dibuktikan dengan surat pernyataan yang bersangkutan diketahui Ketua RT/ RW/ Lurah/Kepala Desa setempat, atau berita acara penelitian lapangan dari kantor pertanahan setempat

e. Surat-surat lain yang berkaitan dengan permohonan pembatalan, apabila diperlukan dapat dipersyaratkan oleh Kepala Bidang atau Direktur yang bertanggung jawab menangani perkara pada Direktorat Jenderal.

Setelah permohonan diterima, pejabat yang bertanggung jawab menangani Sengketa, Konflik, dan Perkara melakukan penelitian berkas permohonan. Berdasarkan hasil penelitian berkas permohonan tersebut di lakukan analisis putusan pengadilan. Dalam hal terdapat kekurangan data, maka pejabat yang bertanggung jawab menangani Sengketa, Konflik dan Perkara melakukan pengumpulan data dan kepala kantor pertanahan menyampaikan hasil analisis putusan pengadilan disertai data pendukung yang telah di kumpulkan kepada:

a. Kepala Kantor Wilayah Badan Pertanahan Nasioanal, dalam hal keputusan pemberian hak, koversi/penegasan/pengakuan, Pembatalan sertipikat hak atas tanah yang diterbitkan oleh Kepala Kantor Pertanahan;atau

b. Menteri, dalam hal keputusan pemberian hak, konversi/ penegasan/ pengakuan, pembatalan hak atas tanah, atau penetapan tanah terlantar yang diterbitkan oleh Kepala Kantor Wilayah Badan Pertanahan nasional atau Menteri. 
Setelah menerima hasil analisis putusan pengadilan, Kepala Kantor wilayah Badan Pertanahan Nasional atau Menteri memerintahkan pejabat yang bertanggung jawab dalam menangani sengketa, konflik dan perkara untuk melakukan :

a. Melakukan pengkajian dan pemeriksaan lapangan;

b. Melakukan paparan, apabila diperlukan;dan

c. Menyusun dan menyampaikan Laporan Penyelesaian Perkara.

Kegiatan tersebut berlaku sama (mutatis mutandis) terhadap Pejabat Pemerintah yang bertanggung jawab dalam rangka melaksanakan putusan pengadilan. Dalam hal pelaksanaan putusan pengadilan, pelaksanaannya dilakukan sesuai dengan kewenangan pembatalan. Kewenangan pembatalan meliputi:

a. Kepala Kantor Pertanahan, dalam hal keputusan konversi/ penegasan/ pengakuan, pemberian hak, pembatalan hak yang diterbitkan oleh Kepala Kantor Pertanahan;

b. Kepala Kantor Wilayah Badan Pertanahan Nasional, dalam hal keputusan konversi/ penegasan/ pengakuan, pemberian hak, pembatalan hak yang diterbitkan oleh Kepala Kantor Wilayah Badan Pertanahan Nasional;

c. Menteri dalam hal keputusan pemberian hak, keputusan pembatalan hak, keputusan penetapan tanah terlantar yang diterbitkan oleh menteri .

Penerbitan keputusan pembatalan yang dilakukan oleh Kepala Kantor Pertanahan dan Kepala Kantor Wilayah Badan Pertahanan Nasional ,dilakukan atas nama Menteri dan dilaporkan kepada Menteri dalam jangka waktu 7 (tujuh) hari kerja sejak keputusan pembatalan diterbitkan.

Dalam hal tanah objek putusan pengadilan merupakan aset barang milik negara/daerah dan/atau aset badan usaha milik negara/daerah, pelaksanaan pembatalan hak atas tanahnya dilakukan tanpa menunggu proses penghapusan aset/aktiva tetap dari instansi yang bersangkutan. Setelah dilaksanakan pembatalan, kepala kantor pertanahan memberitahukan kepada pemegang aset yang hak atas tanahnya dibatalkan agar dilakukan penghapusan aset /aktiva tetap. Pemberian hak atas tanah dilakukan setelah adanya penghapusan aset /aktiva tetap dari instansi yang bersangkutan.

Pelaksanaan putusan pengadilan yang telah mempunyai kekuatan hukum tetap (inkracht van gewijsde) wajib dilaksanakan kecuali terdapat alasan yang sah untuk tidak melaksanakannya. Sebagaimana dinyatakan dalam pada Pasal 58 ayat (2) alasan yang sah , antara lain :

a. Terhadap obyek putusan terdapat putusan lain yang bertentangan ; pelaksanaan pembatalan terhadap obyek putusan terdapat putusan lain yang bertentangan setelah adanya putusan yang telah berkekuatan hukum tetap.

b. Terhadap obyek putusan sedang dalam status diblokir atau disita oleh kepolisian, kejaksaan, pengadilan dan/atau lembaga penegak hukum lainnya. Pelaksanaan pembatalan terhadap obyek putusan sedang dalam status diblokir atau sita oleh kepolisian, kejaksaan, pengadilan dan/atau lembaga penegak hukum lainnya, setelah adanya pencabutan sita dari kepolisian, kejaksaan, pengadilan dan/atau lembaga penegak hukum lainnya. 
c. Alasan lain yang diatur dalam ketentuan peraturan perundang-undangan.

Alasan tersebut dilaporkan oleh Kepala Kantor Pertanahan kepada Kepala Kantor Wilayah Badan Pertanahan Nasional atau Menteri dalam waktu paling lama 7 (tujuh) hari kerja sejak diterimanya keputusan. Pelaksanaan pembatalan terhadap objek putusan terdapat putusan lain yang bertentangan dilaksanakan setelah adanya putusan yang telah berkekuatan hukum tetap.

\section{Proses Pembatalan Sertipikat Hak Milik Berdasarkan Putusan Pengadilan Tata Usaha} Negara.

Pada pembatalan sertipikat hak milik berdasarkan Putusan Pengadilan Tata Usaha Negara, berdasarkan Pasal 116 Undang-undang Nomor 5 Tahun 1986 Tentang Peradilan Tata Usaha Negara, langkah pertama yang ditempuh yaitu penyampaian salinan putusan pengadilan yang telah mempunyai kekuatan hukum tetap oleh panitera atas perintah ketua pengadilan yang mengadilinya pada tingkat pertama kepada para pihak dengan surat tercatat selambat-lambatnya dalam waktu 14 (empat belas) hari kerja.

Setelah 60 (enam puluh) hari sejak salinan putusan pengadilan tersebut dikirimkan kepada tergugat, tidak melaksanakan kewajibannya sebagaimana dimaksud dalam Pasal 97 ayat (9) huruf a yaitu mencabut Keputusan Tata Usaha Negara yang disengketakan, maka Keputusan Tata Usaha Negara yang disengketakan itu dinyatakan tidak mempunyai kekuatan hukum lagi. Dalam hal putusan pengadilan tersebut mewajibkan kepada tergugat untuk melaksanakan:

a. Kewajiban pencabutan Keputusan Tata Usaha Negara yang bersangkutan (yang digugat). Dalam hal ini berlaku ketentuan dalam Pasal 116 ayat (2) Undang-undang Peradilan Tata Usaha Negara yang menyatakan bahwa dalam hal 60 (enam puluh) hari kerja setelah putusan Pengadilan yang telah memperoleh kekuatan hukum tetap sebagaimana dimaksud dalam ayat (1) dikirimkan tergugat tidak melaksanakan kewajibannya sebagaimana dimaksud dalam Pasal 97 ayat (9) huruf a maka Keputusan Tata Usaha Negara yang disengketakan itu tidak mempunyai kekuatan hukum lagi. Konsekuensi dari ketentuan ini terhadap keputusan yang disengketakan dan telah diputuskan tersebut tidak perlu ada tindakan atau upaya lain lagi dari pengadilan. Misalnya, adanya surat peringatan dan sebagainya. Paulus Effendi Lotulung menyebutnya dengan eksekusi otomatis (Yuslim, 2015:160).

b. Kewajiban pencabutan Keputusan Tata Usaha Negara dan menerbitkan Keputusan Tata Usaha Negara yang baru atau Kewajiban Penerbitan Keputusan Tata Usaha Negara dalam hal gugatan didasarkan pada Pasal 3. Dalam hal ini, berlaku ketentuan dalam Pasal 116 ayat (3) yang menyatakan bahwa dalam hal tergugat ditetapkan harus melaksanakan kewajibannya sebagaimana dimaksud dalam Pasal 97 ayat (9) huruf b dan huruf c, dan setelah 90 (sembilan puluh) hari kerja ternyata kewajiban tersebut tidak dilaksanakannya maka penggugat mengajukan permohonan kepada Ketua Pengadilan sebagaimana dimaksud dalam ayat (1) agar Pengadilan memerintahkan tergugat melaksanakan putusan pengadilan tersebut (Yuslim, 2015:161). 
Setelah 90 (Sembilan puluh) hari kerja sejak putusan pengadilan tersebut diberitahukan kepada tergugat ternyata kewajiban tersebut tidak dilaksanakan oleh tergugat, maka penggugat mengajukan permohonan kepada Ketua Pengadilan yang bersangkutan agar Ketua Pengadilan memerintahkan Tergugat untuk melaksanakan putusan pengadilan tersebut. Sesudah Tergugat diperintahkan oleh Ketua Pengadilan untuk melaksanakan putusan pengadilan tersebut, ternyata tergugat tidak bersedia melaksanakan putusan pengadilan yang telah memperoleh kekuatan hukum tetap, maka berdasarkan Pasal 116 ayat (4) terhadap pejabat yang bersangkutan dikenakan upaya paksa berupa pembayaran sejumlah uang paksa dan/atau sanksi administratif.

Hal ini dilandasi prinsip karena Sengketa Tata Usaha Negara berawal dari Keputusan Tata Usaha Negara (administrasi negara), setelah pengadilan menjatuhkan putusan, jika pejabat tetap tidak mau melaksanakan kewajiban yang dibebankan kepadanya persoalan itu dikembalikan lagi kepada administrasi negara tersebut, yakni melalui paksaan Pemerintah (bestuur dwang). Dari segi administrasi negara atau penyelenggaraan pemerintahan, paksaan ( $d$ wang) yang lebih efektif adalah paksaan yang datang dari atasan seorang pejabat, jadi pembuat Undang-undang lebih memilih paksaan pemerintah (bestuur dwang) agar Pejabat Tata Usaha Negara mematuhi putusan pengadilan (Yuslim, 2015:161).

Paksaan Pemerintah yang dapat dikenakan terhadap pejabat yang bersangkutan berupa pembayaran sejumlah uang paksa dan atau sanksi administratif. Uang paksa yang dimaksud adalah pembebanan berupa pembayaran sejumlah uang yang ditetapkan oleh hakim karena jabatannya yang dicantumkan dalam amar putusan pada saat mengabulkan gugatan penggugat (Yuslim, 2015:162).

Kemudian pejabat yang tidak melaksanakan putusan pengadilan Tata Usaha Negara akan diumumkan pada media massa cetak setempat oleh panitera sejak tidak terpenuhinya ketentuan sebagimana dimaksud pada Pasal 116 ayat (3). Pengumuman di media masa setempat harus dilakukan oleh Panitera dan bersifat mengikat (imperatif). Dengan adanya pengumuman di media masa setempat akan diketahui bahwa pejabat tertentu yang tidak mematuhi putusan pengadilan. Di samping diumumkan pada media massa cetak setempat, ketua pengadilan harus mengajukan hal ini kepada presiden sebagai pemegang kekuasaan pemerintah tertinggi untuk memerintahkan pejabat tersebut melaksanakan putusan pengadilan, dan kepada lembaga perwakilan rakyat untuk menjalankan fungsi pengawasan.

Tujuan menyampaikan kepada Presiden karena Presiden sebagai pemimpin tertinggi pemerintah berkewajiban untuk melakukan pembinaan terhadap aparatur Pemerintah yang tidak menjalankan fungsi pemerintahan dengan baik. Adapun penyampaian kepada lembaga perwakilan rakyat adalah karena fungsi dewan untuk melakukan kontrol terhadap eksekutif. Dengan demikian lembaga perwakilan rakyat juga wajib mengetahui kepatuhan instansi yang diawasinya terhadap putusan pengadilan.

Berdasarkan penelitian terhadap perbedaan proses pembatalan sertipikat hak milik berdasarkan putusan peradilan umum dan pembatalan sertipikat hak milik berdasarkan putusan Pengadilan Tata Usaha Negara, penulis menyimpulkan bahwa pembatalan sertipikat hak milik yang penulis jadikan penelitian seharusnya tetap melalui putusan Pengadilan Tata Usaha Negara 
karena termasuk dalam kewenangan Peradilan Tata Usaha Negara berdasarkan Pasal 47 UndangUndang Nomor 5 Tahun 1986 Tentang Peradilan Tata Usaha Negara yang menegaskan bahwa "Pengadilan bertugas dan berwenang memeriksa, memutus, dan menyelesaikan sengketa Tata Usaha Negara". Sedangkan yang dimaksud dengan sengketa Tata Usaha Negara berdasarkan Pasal 1 angka 10 Undang-Undang Nomor 5 Tahun 1986 Tentang Peradilan Tata Usaha Negara dijelaskan bahwa "Sengketa yang timbul dalam bidang Tata Usaha Negara antara orang/badan hukum perdata dengan pejabat Tata Usaha Negara baik di Pusat maupun di Daerah, sebagai akibat dikeluarkannya keputusan Tata Usaha Negara, termasuk sengketa kepegawaian berdasarkan peraturan perundang-undangan yang berlaku".

Berdasarkan uraian di atas dapat disimpulkan bahwa permasalahan mengenai pembatalan sertipikat hak milik yang dikeluarkan oleh Kantor Pertanahan Kabupaten Agam sebagai pelaksanaan putusan Pengadilan Negeri Lubuk Basung dalam perkara Nomor: 17/PDT.G/2009/PN.LB.BS termasuk dalam kewenangan (absolut) dari Peradilan Tata Usaha Negara.

\section{Proses Pembatalan Sertipikat Hak Milik Berdasarkan Putusan Pengadilan Yang Berkekuatan Hukum Tetap Dalam Perkara Nomor : 17/PDT.G/2009/PN-LB.BS.}

Berdasarkan penelitian pada putusan Pengadilan terhadap Perkara Nomor :17/PDT.G/2009/PN-LB.BS yang berkekuatan hukum tetap (inkracht van gewijsde) yang amar putusannya menyatakan tidak sah dan tidak mempunyai kekuatan hukum sebanyak 13 (tiga belas) sertipikat hak milik atas tanah, putusan tersebut tidak serta merta dapat membatalkan sertipikat-sertipikat tersebut, karena Pengadilan Negeri Lubuk Basung menyatakan bahwa pembatalan sertipikat tanah bukan kewenangan Pengadilan Negeri, Pengadilan Negeri hanya berwenang sebatas gugatan kepemilikan hak atas tanah, sehingga Pengadilan Negeri tidak memiliki kewajiban lagi dalam melakukan pengawasan terhadap pelaksanaan putusan. Putusan Pengadilan Negeri tersebut hanya digunakan sebagai salah satu syarat pengajuan pembatalan ke Kantor Pertanahan. Dalam proses pembatalan sertipikat tanah yang harus diketahui adalah mengenai siapa yang berwenang membatalkan hak milik.

Penanganan kasus pertanahan dimaksudkan untuk memberikan kepastian hukum atas penguasaan, pemilikan, penggunaan dan pemanfaatan tanah untuk memastikan tidak terdapat tumpang tindih penggunaan, pengusaan dan pemilikan tanah. Penanganan kasus pertanahan untuk memastikan pemanfaatan penggunaan dan pemilikan sesuai ketentuan peraturan perundang-undangan serta bukti kepemilikan tanah bersifat tunggal untuk setiap bidang tanah yang diperselisihkan.

Berdasarkan hasil penelitian pada Kantor Pertanahan Kabupaten Agam, penulis menyimpulkan kendala-kendala yang timbul pada proses pembatalan sertipikat hak milik atas tanah antara lain:

a. Sertipikat yang akan dibatalkan sedang dalam status diblokir, disita oleh pejabat yang berwenang (conservatoir beslag); 
b. Sertipikat yang dimohon pembatalannya merupakan tanah yang objek perkara lainnya di pengadilan;

c. Pelaksanaan pembatalan diperkirakan dapat menimbulkan gejolak sosial/konflik massal;

d. Tidak tersedianya anggaran untuk melaksanakan pembatalan pada tahun tersebut;

e. Masih terdapat hak-hak lain yang melekat diatas tanah objek perkara seperti hak tanggungan, sehingga menyulitkan Kantor Pertanahan Kabupaten Agam untuk segera memproses permohonan pembatalan sertipikat, Kantor Pertanahan Kabupaten Agam akan menunggu para pihak menyelesaikan hak-hak lain yang melekat diatas tanah objek perkara terlebih dahulu karena hal tersebut bukan merupakan kewenangan pembatalan sertipikat pada Kantor Pertanahan Kabupaten Agam.

f. Tergugat tidak mau menyerahkan tanah yang dikuasainya kepada penggugat meskipun telah dikeluarkan putusan yang sudah mempunyai kekuatan Hukum Tetap (inkrach van gewijsde) oleh pengadilan.

g. Belum adanya permohonan pembatalan yang diajukan.

Dalam menangani kasus pertanahan mengenai kompetensi peradilan dalam mengadili kasus pertanahan khususnya gugatan terhadap sertipikat hak milik dimulai sejak terbentuknya peradilan tata usaha negara, karena sebelumnya kasus pertanahan diselesaikan melaui peradilan umum. Dengan adanya peradilan tata usaha negara, mengakibatkan persoalan gugatan Pembatalan sertipikat hak atas tanah sulit didefinisikan secara tegas. Kesalahan identitifikasi yuridiksi materil suatu perkara akan mengakibatkan tidak diterimanya gugatan atau ketidaksempurnaan putusan pengadilan (Hasan Basri Nata Menggala, dan Sarjita, 2005:72). Hal ini menjadi salah satu akibat tidak dapatnya amar putusan tersebut dijalankan sehingga menimbulkan kerugian bagi pencari keadilan itu sendiri.

Terhadap putusan yang dikeluarkan oleh Pengadilan Negeri dan Pengadilan Tata Usaha Negara bagi Badan Pertanahan Nasional sama saja. Putusan Pengadilan Tata Usaha Negara yang menyatakan batal sertipikat bukan berarti sertipikat tersebut otomatis batal, hakim Pengadilan Tata Usaha Negara sendiri menyebutkan bahwa hanya sedikit orang yang mengajukan pembatalan ke Pengadilan Negeri harus digugat lagi pembatalan ke Pengadilan Tata Usaha Negara. Hakim pun memiliki persepsi sendiri-sendiri dalam memproses perkara.

Dari uraian diatas sudah jelas batas wewenang masing-masing peradilan akan tetapi pada prakteknya seringkali suatu gugatan perdata dengan objek sertipikat hak atas tanah mengandung aspek Tata Usaha Negara dan juga pada gugatan Tata Usaha Negara memuat aspek keperdataan . Hal ini terjadi karena hak-hak keperdataan yang digugat pada peradilan umum terkait dengan sertipikat sebagai Keputusan Tata Usaha Negara, sebaliknya pada Peradilan Tata Usaha Negara umumnya gugatan mengenai sertipikat diterbitkan dengan alas hak yang merupakan bukti hak keperdataan seseorang. 


\section{Akibat Hukum Terhadap Sertipikat Hak Milik Dengan keluarnya Putusan Pengadilan yang Berkekuatan Hukum Tetap (Inkracht Van Gewijsde).}

Dari hasil penelitian di Kantor Pertanahan Kabupaten Agam, setidaknya ada tiga hal utama yang menyebabkan terjadinya sengketa tanah yaitu:

Pertama, Adanya kepemilikan komunal dan keberadaan hak ulayat masyarakat hukum adat.

Kedua, Distribusi kepemilikan tanah yang tidak merata baik untuk tanah pertanian maupun bukan pertanian telah menimbulkan ketimpangan baik secara ekonomi, politis maupun sosiologis. Dalam hal ini, masyarakat bawah, khusunya petani/penggarap tanah memikul beban paling berat. Ketimpangan distribusi tanah ini tidak terlepas dari kebijakan ekonomi yang cenderung kapitalistik, dan leberalistik. Atas nama pembangunan tanahtanah garapan petani atau tanah milik masyarakat adat dapat diambil alih oleh para pelaku usaha.

Ketiga, Legalitas kepemilikan tanah yang semata-mata didasarkan ada bukti formal (sertipikat), tanpa memperhatikan produktivitas tanah. Akibatnya secara legal (de jure), boleh jadi banyak tanah bersertipikat dimiliki oleh perusahan atau para pemodal besar, karena mereka telah membelinya dari para petani/pemilik tanah, tetapi tanah tersebut lama ditelantarkan begitu saja.

Dari hasil penelitian perkara pembatalan sertipikat hak milik atas tanah dengan Putusan perkara Nomor 17/PdT.G/2009/PN-LB.BS diketahui bahwa pembatalan sertipikat hak milik yang diajukan pada dasarnya mengenai proses penerbitan sertipikat hak milik yang melanggar peraturan Perundang-undangan. Berdasarkan Undang-undang Nomor 30 Tahun 2014 tentang Administrasi Pemerintahan, maka penulis menyimpulkan bahwa akibat hukum terhadap sertipikat hak milik atas tanah dengan keluarnya putusan pengadilan yang berkekuatan hukum tetap (inkracht van gewijsde) adalah sebagai berikut:

a. Batalnya sertipikat hak milik. Dalam hal keputusan dibatalkan, Badan dan/atau Pejabat Pemerintahan menarik kembali semua dokumen, arsip, dan/atau barang yang menjadi akibat hukum dari keputusan atau menjadi dasar penetapan keputusan (Pasal 67 Undangundang Nomor 30 Tahun 2014 tentang Administrasi Pemerintahan).

b. Tidak mengikat sertipikat hak milik atas tanah sejak keputusan dan/atau tindakan pembatalan ditetapkan atau tetap sah sampai adanya pembatalan (Pasal 70 ayat (2) huruf a Undang-undang Nomor 30 Tahun 2014 tentang Administrasi Pemerintahan).

c. Segala akibat hukum yang ditimbulkan sebelum sertipikat dibatalkan dianggap tidak pernah ada ( Pasal 70 ayat (2) huruf b Undang-undang Nomor 30 Tahun 2014 tentang Administrasi Pemerintahan).

d. Pemegang sertipikat hak milik kehilangan haknya, pemilik dokumen, arsip, dan/atau barang wajib mengembalikannya kepada Badan dan/atau Pejabat Pemerintahan yang menetapkan pembatalan Keputusan.

e. Pemilik yang sebenarnya atas tanah dapat memperoleh haknya kembali. 
f. Batalnya akta turunan akibat pembatalan sertipikat hak milik atas tanah seperti akta jual beli apabila tanah tersebut telah diperjual balikan kepada pihak ketiga sebelum sertipikat tersebut batal.

g. Batalnya hak-hak yang melekat diatas tanah seperti hak tanggungan.

Berdasarkan hasil penelitian, hukum ternyata belum dapat dijadikan sebagai barometer untuk menegakkan kebenaran atas status tanah. Dimana setelah keluarnya putusan-putusan Pengadilan tidak dapat langsung dilaksanakan pembatalan sertipikatnya oleh Badan Pertanahan Nasional. Akhirnya, tumpang tindih kepemilikan lahan antar masyarakat memerlukan penyelesaian cukup lama yang melibatkan berbagai pihak. Situasi tumpang tindih tersebut menunjukkan kelalaian dalam mengimplementasikan Pasal 19 ayat (1) dan (2) UUPA serta kekosongan hukum untuk memberikan sanksi (punishment) kepada masyarakat yang telah mengajukan dokumen palsu atas suatu bidang bidang tanah. Hal ini untuk mencapai tertib administrasi, menegakkan keadilan dan memberikan perlindungan bagi pihak ketiga.

\section{KESIMPULAN}

Hasil penelitian menunjukkan bahwa masih terdapat kendala dalam proses pembatalan sertipikat hak atas tanah sehingga menimbulkan ketidakpastian hukum bagi masyarakat yang ingin memperoleh haknya. Selain itu, proses pembatalan sertifikat hak milik atas tanah berdasarkan putusan pengadilan yang berkekuatan hukum tetap (inkracht van gewijsde) pada Kantor Pertanahan Kabupaten Agam, belum memenuhi ketentuan yang diatur pada Pasal 53 undang-undang nomor 30 tahun 2014 Tentang Administrasi Pemerintahan dan Pasal 116 Undang-Undang nomor 5 Tahun 1986 Tentang Peradilan Tata Usaha Negara Usaha Negara terutama dalam hal jangka waktu pelaksanaan pembatalan yang masih cenderung lama sehingga menimbulkan ketidakpastian hukum bagi masyarakat yang ingin memperoleh haknya. Hal ini disebabkan oleh tidak adanya pengaturan yang tegas mengenai proses pembatalan sertipikat berdasarkan putusan pengadilan yang berkekuatan hukum tetap seiring terjadinya tumpang tindih kewenangan peradilan yang menangani kasus sengketa pertanahan. Kemudian batalnya sertifikat hak atas tanah menyebabkan Segala akibat hukum yang ditimbulkan sebelum sertifikat dibatalkan dianggap tidak pernah ada. Hal ini jelas bertentangan dengan ketentuan dalam Pasal 32 ayat (2) Peraturan Pemerintah Nomor 24 Tahun 1997 Tentang Pendaftaran Tanah dan Surat Edaran Mahkamah Agung Nomor : 07 Tahun 2012 tentang Rumusan Hukum Hasil Rapat Pleno Kamar Mahkamah Agung sebagai pedoman pelaksanaan tugas bagi pengadilan khususnya pada poin ke IX.

\section{DAFTAR PUSTAKA}

AP. Parlindungan, Pendaftaran Tanah Di Indonesia, CV Mandar Maju, edisi cetakan ke II, 1994,

Hasan Basri Nata Menggala, dan Sarjita, Pembatalan Dan Kebatalan Hak Atas Tanah, Tugujogja Pustaka, Yogyakarta, 2005, 
Yahya Harahap, Ruang Lingkup Permasalahan Eksekusi Bidang Perdata, Sinar Grafika, Jakarta, 2007 ,

Yuslim, Hukum Acara Peradilan Tata Usaha Negara, Sinar Grafika, Jakarta, 2015.

Zairin Harahap, 2008, Hukum Acara Peradilan Tata Usaha Negara, PT. Raja Grafindo Persada, Jakarta,

Undang undang Nomor 11 Tahun 2016 Tentang Penyelesaian Kasus Pertanahan

https://www.jurnalhukum.com/pendaftaran-tanah/, pada tanggal 20 Februari 2020 pukul 15.20 WIB. 